\title{
Investigation of Mathematics Teacher Candidates' Conceptual Structures about "Measurement" through Word Association Test: The Example of Turkey
}

\author{
Ahmet Erdogan \\ Correspondence: Ahmet Erdogan, Ahmet Kelesoglu Faculty of Education, Necmettin Erbakan University, Konya, \\ 42090, Turkey.
}

Received: October 24, 2017

doi:10.11114/jets.v5i12.2733

\author{
Accepted: November 23, $2017 \quad$ Online Published: November 28, 2017 \\ URL: https://doi.org/10.11114/jets.v5i12.2733
}

\begin{abstract}
The purpose of this research is to determine mathematics teacher candidates' conceptual structures about the concept of "measurement" that is the one of the important learning fields of mathematics. Qualitative research method was used in this study. Participants of this study were 58 mathematics teacher candidates studying in one of the public universities in Turkey. The free word-association test was used as data collection tool. The "Measurement" stimulus concept was presented to mathematics teacher candidates through the free word-association test. A total of 118 response words obtained from the test have been arranged in frequency tables. The response words divided into 9 categories with the help of content analysis. A network of concepts has been created that the conceptual structures of mathematics teacher candidates about "measurement" using the frequencies and categories of response words. The findings of this study indicates that the response words with the highest frequency of the mathematics teacher candidates related to the "measurement" stimulus word are evaluation, exam, length, meter, test, etc. and the categories of response words are meaning of measurement, measurement and evaluation lesson, measurement learning domain, measurement in daily life, measurement units, etc.
\end{abstract}

Keywords: measurement, conceptual structure, free word association test, mathematics teacher candidates

\section{Introduction}

Mathematical knowledge is generally considered as conceptual and procedural knowledge (Skemp, 1978, 1987). Since traditional learning-teaching environments hold procedural knowledge in the foreground, mathematics is taught more on the basis of memorization, so meaningful learning cannot be achieved. However, in order to learn mathematics, conceptual knowledge should be at least as important as procedural knowledge (Hiebert and Lefevre, 1986; Olkun and Toluk, 2004, Rittle-Johnson Siegler and Alibali, 2001). By balancing the conceptual and procedural knowledge, it becomes easier for students to reveal high-order thinking skills necessary for understanding mathematics, to make assumptions, to make generalizations and to make connections between them (Bekdemir, 2012; Gurbuz and Birgin, 2009; Post and Cramer, 1989; Rittle-Johnson and Kaedinger, 2009). When people learn new things, they build on their previous knowledge. Similarly, mathematical knowledge is incorporated into existing knowledge (Papadakis, Kalogiannakis, and Zaranis, 2016). When new knowledge can be associated and reconciled appropriately with the old knowledge, then the understanding of the concept occurs (Baki and Kartal, 2004, CCSSI, 2010; Erdogan, 2007; NCTM, 2000).

One of the basic concepts of mathematics is the measure. Measurement is a concept that has many meanings in it and has an important place in mathematics. Bright (1976) defines measurement as the defined quality of a physical object as a comparison with a unit chosen to determine the quantity of that quality. In this definition it is seen that the measure is a comparative work, and contains the concepts of quality, quantity and unit. When measuring, it is seen that two objects are basically compared in terms of the same qualities. In this comparison, a quantity is obtained and this quantity is expressed in a unit. As a result, the structure composed of these, comparative-quality-quantity-unit, quartets is called measurement in mathematics (Zembat, 2013). It is possible to see many applications of the measurement process in daily life. Beside this, measurement is generally seen in two places in mathematics education. The first is as a learning field of mathematics and the second is as a course of measurement and assessment in teacher education.

The learning areas covered in school mathematics are defined as "numbers-operations, geometry, measurement, data 
and algebra" (MEB-TTKB, 2005; NCTM, 2000). Although the measurement is considered as a learning area on its own in mathematics teaching programs, it is considered as a continuation of the geometry learning area in practice. It is a fact that many concepts in these two learning areas are prerequisites for the other concepts. For example, the concept of "angle measurement" can not be gained without gaining the "angle" concept in geometry. Similarly, "polygons" is prerequisite for "measuring the perimeter of polygons", while "geometric objects" is prerequisite for "volume measurement" and "liquid measurement".In the mathematics curriculum, the measurement of different qualities and different measurement units are emphasized. In these programs, length, area, volume, time, mass, etc.; and as a unit, standard and non-standard measurement units are mentioned at almost all levels of education (MEB-TTKB, 2017). Within the scope of Measurement and Evaluation course, basic concepts related to measurement and evaluation, measurement types, statistical techniques, scales are taught. In practice, the approach, dealing with measurement subjects as the complementary subject of geometry rather than detailed discuss of measurement subjects can lead to problems in learning the subjects related to measurement (Delil and Gules, 2007). Morover, since the subjects in this learning field is underestimated, teachers and students have difficulty in explaining the concepts related to this topic. In this sense, the concept of measurement has a very important place for those who are engaged in mathematics education and it is important to determine the cognitive structures of teacher candidates about this concept.

Along with the widespread adoption of the constructivist learning approach in learning environments, alternative assessment-evaluation techniques have begun to take place of traditional assessment-evaluation techniques. One of these measurement-evaluation techniques is free word association test. Being easy and fast to prepare, applicable at all class levels, and allowing for individual or group practice, it has been a technique frequently used in learning environments recently. In free word association test, key concepts or concepts related to a topic are given to the students. Students are asked to rank the words evoked by this concept given within a short time and then the responses given are analyzed. The frequency tables of the words that the students give as response are formed. Thus, it is assumed that the sequential responses of a student to a key concept show long-term memory, semantic proximity between concepts in cognitive structure, and semantic proximity of concepts (Bahar, Johnston and Sutcliffe, 1999). According to semantic closeness and semantic distance effect, if two concepts are close to each other in terms of distance, they have close relationship, and during recall mental search will be rapid that the response related to these two concepts will be quick (Bahar et al. 1999; Özatl1, 2006). There are many studies in the literature to determine cognitive structure using the free word association test (Ay, 2011; Bahar et al., 1999; Daskolia, Flogitis and Papageorgiou, 2006; Dikmenli, 2010a; Dikmenli, 2010b; Kostova and Radoynovska, 2010; Kurt and Ekici, 2013a; Kurt and Ekici, 2013b; Ozata-Yucel and Ozkan, 2015; Schmitt, 1998) that there are studies especially to reveal the cognitive structures of mathematics teacher candidates about the concepts; function, limit, continuity, probability, statistics, geometry, trigonometry etc. (Benibil and Erdogan, 2016, Benibil and Erdogan, 2016b, Erdogan, 2017, Gokbas and Erdogan, 2016, Keser, 2016, Turan and Erdogan, 2016, Turan and Erdogan, 2017). It is seen that the studies related to the measurement are mostly the ones that reveal the problems that the teacher candidates have experienced in the assessment and evaluation techniques (Birgin \& Gurbuz, 2008; Gelbal \& Kelecioglu, 2007; Senel-Coruhlu, Er-Nas, Cepni, 2009).

The purpose of this research is to determine mathematics teacher candidates' conceptual structures about the concept of "measurement" using free word association test. For this purpose, in this study, "How are the conceptual structures of the mathematics teacher candidates related to the concept of "measurement'?" question is searched for an answer.

\section{Method}

In this research, phenomenological approach that is one of the qualitative research approaches is used. Phenomenological approach is used to research the phenomenon that we aware but have difficulty in comprehending (Yıldırım and Simsek, 2006).

\subsection{Participants}

This study was conducted with 58 mathematics teacher candidates studying in one of the public universities in Turkey during spring term of 2016-2017 academic year. Teacher candidates participated in the research were selected through purposeful sampling, and they were preferred because they are at their last semester of the mathematics teacher's program that they completed all content and pedagogy courses. In order to reduce the problems in purposeful sampling (Coyne, 1997; Given, 2008; Knight et al., 2013), criterias such as volunteerism and easily accessibility of the researcher have been taken into consideration. The number of teacher candidates was $40(69 \%)$ male and $18(31 \%)$ female that the average of the participants was 22,4 years (range 21-25).

\subsection{Data Collection}

The data of the study were collected using Free Word Association Test. With the free word association test, it is aimed to collect detailed data on the participants' conceptual structure about the concept "measurement". The word association test consists of two steps. In the first step, the participants have to write the first ten words they bring to the mind of the 
stimulating word within a certain period of time. In the second step, participants are asked to write sentences about the stimulant word within a certain period of time. Since the second step is used more often in the determination of conceptual misconceptions about the given concept, the analysis of the data in this step of the study has not been analyzed. With the free word association test, the "measurement" stimulus concept was presented to mathematics teacher candidates as seen in Figure 1, written 10 times one under the other.

\begin{tabular}{|c|}
\hline Stimulus Concept: MEASUREMENT \\
\hline MEASUREMENT:.......... \\
\hline MEASUREMENT:.......... \\
\hline MEASUREMENT:............ \\
\hline MEASUREMENT:................................ \\
\hline MEASUREMENT:............ \\
\hline MEASUREMENT:............ \\
\hline 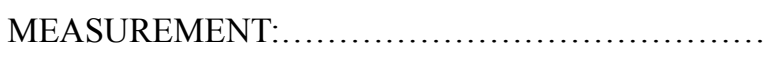 \\
\hline MEASUREMENT:........ \\
\hline MEASUREMENT:....... \\
\hline MEASUREMENT:...... \\
\hline
\end{tabular}

The reason why the stimulus concept was written one under another is to prevent writing the words coming to mind instead of key concept and eliminate the risk of chain response (Bahar et al., 1999). Teacher candidates were given 30 seconds to complete the test. In order to determine whether the given time is adequate or not literature is investigated and it is thought that duration for the test is suitable (Bahar et al., 1999; Dikmenli, 2010a; Dikmenli, 2010b; Erdogan, 2017; Kurt and Ekici, 2013a; Kurt and Ekici, 2013b). Before the students started the test, the students were informed about the free word association test and the necessary explanations were made using examples.

\subsection{Data Analysis}

The response words given by the teacher candidates to the stimulus concept presented with the free word association test were examined by the content analysis method. The main aim in content analysis is to reach concepts and associations that can explain data. Therefore, similar data are gathered in the framework of certain concepts and categories, and they are organized and interpreted in a way that reader can understand (Lichtman, 2010; Stemler, 2001; Weber, 1990; Wimmer and Dominick, 2000). Content analysis is a scientific approach that allows verbal, written and other materials to be examined objectively and organized systematically into specific categories. (Bogdan and Biklen, 2007; Cohen et al., 2007). The steps for the analysis and interpretation of the answer sheets of the teacher candidates are: (1) examination of papers, (2) elimination of inappropriate papers, (3) recompilation, (4) numbering from 1 to 58 of the answer sheets, (5) developing categories (6) analysing the concepts and placing them into categories (7) providing validity and reliability, (8) calculation of frequency and percentages of concepts and categories obtained, (9) interpretation of data. The data obtained from the free word association test were analyzed using the number of words, number of responses and semantic relationship technique (Atasoy, 2004; Shavelson, 1974). The words answered with the same meaning are categorized under the frequently repeated words. The words that were not related to categories, not related to other words and had no relation with the subject were not evaluated. In many studies, this adopted data analysis technique is expressed to show reliable results (Daskolia et al., 2006; Hovardas and Korfiatis, 2006; Kostova and Radoynovska, 2010).

\subsection{Validity and Reliability}

Validity and reliability are very important issues in qualitative research. In this context, two important processes have been carried out in order to ensure the validity of the results of the research: (1) the coding of the data and the details of how the conceptual categories are achieved within the data analysis process are explained in detail (Hruschka et al., 2004; Daymon and Holloway, 2003). (2) Consistency between the researches about interpretations is tried to provide (Ratcliff, 1995). For this reason, the literature has been examined in detail and it is tried to determine similar and different findings in the researches.

In order to ensure the reliability of the research, the categories of the codes and codes of the two researchers were compared in order to confirm that the codes given under the conceptual categories in the research represented the conceptual categories. After the research data has been separately coded by the two researchers, the final code and category list is constituted. The consistency of codes that researchers use independently from each other has been 
determined by marking them as "Consensus" or "Dissensus". When the researchers use the same codes for the expressions of teacher candidates, it is accepted as consensus, and when they use different codes, it is accepted as dissensus. In sections where a researcher runs into a contradiction, the opinion of other researcher is used for coding. The reliability of the analysis made in this way calculated using the formula [consensus / (consensus + dissensus) $\mathrm{x} 100$ ] (Miles \& Huberman, 1994). The average reliability between the encoders was found as $90 \%$.

\section{Results}

In this part, first of all, the responses of mathematics teacher candidates' to the stimulus concept "measurement" in free word association test and categories obtained from the response words are given as frequency tables. Afterwards, the conceptual structure model of teacher candidates about the concept of "measurement" is given in the form of concept network.

\subsection{Findings Related to the Response Words Given to Stimulus Concept "Measurement" and Created Categories}

A total of 527 responses are obtained from free word association test applied to teacher candidates about "measurement" stimulus concept. 118 different words obtained from these responses are organized in 9 categories and these categories are shown in Table 1. If the response words are not meaningful or irrelevant to the subject, they are not received for consideration (Daskolia et al., 2003; Kostova \& Radoynovska, 2008; Torkar \& Bajd, 2006). Therefore, 18,6\% (27 words) is not included in the categories.

Table 1. The Categories Organized Using the Responses for "Measurement" Stimulus Concept

\begin{tabular}{lll}
\hline Categories & Frequency (f) & $\%$ \\
\hline 1. Meaning of Measurement & 168 & 31,9 \\
2. Measurement and Evaluation Lesson & 70 & 13,3 \\
3. Measurement Learning Domain & 63 & 12,0 \\
4. Measurement in Daily Life & 56 & 10,6 \\
5. Measurement Units & 49 & 9,3 \\
6. Techniques in Measurement and Evaluation & 38 & 7,2 \\
7. Measurand & 31 & 5,9 \\
8. Scale & 27 & 5,1 \\
9. Measurement Tools & 25 & 4,7 \\
\hline
\end{tabular}

As a result of the data analysis, the responses of teacher candidates regarding the measurement key concept are heavily related to the meaning of "measurement". Therefore, this category is called "Meaning of Measurement" and it is the category with the highest frequency $(\mathrm{f}=168)$. In this category, the most focused concept is Evaluation, followed by the concepts of Testing, Measuring/Measure, Result, Calculation, Comparing, Ordering, Classification, Checking, Equaling, Procedure, Condition, Determining, Interpretation, Feedback and Investigation. The response words for "Meaning of Measurement" category and their frequencies are as in Table 2.

Table 2. Response Words in "Meaning of Measurement" Category

\begin{tabular}{llll}
\hline Category & Associations & Frequency (f) & $\%$ \\
\hline & Evaluation & 47 & 28,0 \\
& Testing & 20 & 11,9 \\
& Measuring/Measure & 13 & 7,7 \\
& Result & 11 & 6,5 \\
& Calculation & 10 & 6,0 \\
& Comparing & 10 & 6,0 \\
& Ordering & 6 & 3,6 \\
& Classification & 5 & 3,0 \\
1. Meaning of Measurement & Checking & 4 & 2,4 \\
& Equaling & 4 & 2,4 \\
& Procedure & 3 & 1,8 \\
& Condition & 3 & 1,8 \\
& Determining & 2 & 1,2 \\
& Interpretation & 1 & 0,6 \\
& Feedback & 1 & 0,6 \\
& Investigating & 1 & 0,6 \\
\cline { 2 - 3 } & & 168 & 100 \\
\hline
\end{tabular}

The second category consists of the response words that the teacher candidates have associated with the Measurement and Evaluation course ( $f=70$ ). Therefore, this category is called "Measurement and Evaluation Course". In this 
category, the respondents most associated measurement key concept with the Quantity/Value word. The response words for "Measurement and Evaluation Course" are as in Table 3.

Table 3. Response Words in "Measurement and Evaluation Lesson" Category

\begin{tabular}{llll}
\hline Category & Associations & Frequency (f) & $\%$ \\
\hline & Quantity/Value & 16 & 22,9 \\
& Criterion & 8 & 11,4 \\
& Analyzation & 7 & 10,0 \\
& Data & 6 & 8,6 \\
& Lesson & 5 & 7,1 \\
& Statistics & 4 & 5,7 \\
& Error & 3 & 4,3 \\
& Measurement Techniques & 3 & 4,3 \\
2. Measurement and Evaluation Lesson & Research & 3 & 4,3 \\
& Education/Instruction & 3 & 4,3 \\
& KPSS & 2 & 2,9 \\
& Score/Grade & 2 & 2,9 \\
& Relative evaluation & 2 & 2,9 \\
& Direct/Indirect & 2 & 2,9 \\
& Quantitative & 2 & 2,9 \\
& Qualitative & 2 & 2,9 \\
\cline { 2 - 4 } & TOTAL & 70 & 100 \\
\hline
\end{tabular}

The third category is called "Measurement Learning Domain" ( $f=63)$, since the response words that constitute this category are mainly related to "Measurement" which is an important learning area of Mathematics course. In this category, the response word with highest frequency that is associated with the measurement key concept is Length, the other ones are Area, Volume, Temperature, Time, Mass, Width, etc. The response words for "Measurement Learning Domain" category are as in Table 4.

Table 4. Response Words in "Measurement Learning Domain" Category

\begin{tabular}{llll}
\hline Category & Associations & Frequency (f) & $\%$ \\
\hline & Length & 19 & 30,2 \\
& Area & 7 & 11,1 \\
Volume & 5 & 7,9 \\
Temperature & 5 & 7,9 \\
Time & 4 & 6,3 \\
Mass & 4 & 6,3 \\
& Width & 4 & 6,3 \\
3. Measurement Learning Domain & Distance & 3 & 4,8 \\
& Mathematics & 3 & 4,8 \\
& Height & 3 & 4,8 \\
& Diameter & 1 & 1,6 \\
& Circumference & 1 & 1,6 \\
& Angle & 1 & 1,6 \\
& Density & 1 & 1,6 \\
& Absolute Value & 1 & 1,6 \\
& Geometry & 1 & 1,6 \\
\cline { 2 - 4 } & TOTAL & 63 & 100 \\
\hline
\end{tabular}

The response words that teacher candidates have associated with the daily use of the measure are the fourth category (f =56). In this category, called "Measurement in Daily Life," the key concept "measurement" was associated with Weight, Height, Cut out, Weighing, and etc. The response words for "Measurement in Daily Life" are as in Table 5. 
Table 5. Response Words in "Measurement in Daily Life" Category

\begin{tabular}{llll}
\hline Category & Associations & Frequency (f) & $\%$ \\
\hline & Weight & 19 & 33,9 \\
& Height & 13 & 23,2 \\
& Cut out & 8 & 14,3 \\
& Weighing & 7 & 12,5 \\
& Measuring Fever & 3 & 5,4 \\
4. Measurement in Daily Life & 2 & 3,6 \\
& Race & 2 & 3,6 \\
& Measuring Tension & 1 & 1,8 \\
& Jewelry & 1 & 1,8 \\
\hline & Stethoscope & 1 & 100 \\
\cline { 2 - 4 } & TOTAL & 56 & cheasura
\end{tabular}

The fifth category consists of response words that teacher candidates associate with "measurement" stimulus words with measurement units, and is called "Measurement Units" ( $\mathrm{f}=49$ ). In this category, the response word with the highest frequency when associated with the "measurement" key concept is Meter. Other response words associated by participants in this category are Unit, Centimeter, Span, Degree, Kilometer, Liter, Mile, Foot, Gram, etc. The response words for "Measurement Unit" category are as in Table 6.

Table 6. Response Words in "Measurement Units" Category

\begin{tabular}{llll}
\hline Category & Associations & Frequency (f) & $\%$ \\
\hline & Meter & 17 & 34,7 \\
& Unit & 11 & 22,4 \\
& Centimeter & 4 & 8,2 \\
& Span & 3 & 6,1 \\
& Degree & 3 & 6,1 \\
& Kilometer & 2 & 4,1 \\
& Liter & 2 & 4,1 \\
5. Measurement Units & Mile & 1 & 2,0 \\
& Foot & 1 & 2,0 \\
& Gram & 1 & 2,0 \\
& Kilogram & 1 & 2,0 \\
& Millimeter & 1 & 2,0 \\
& Hectare & 1 & 2,0 \\
& Metric System & 1 & 2,0 \\
\cline { 2 - 4 } & TOTAL & 49 & 100
\end{tabular}

The sixth category is created as "Measurement and Evaluation Techniques" $(f=38)$. In this category, it is seen that the "Measurement" key concept is intensively associated with the Exam response word. Other associated response words consist of different test types or different measurement and evaluation techniques. The response words associated with this category are Exam, Check up Test, Multiple Choice Test, Written Exam, Questionnaire, Observation, True-False Test, Oral Exam, etc. The response words for "Measurement and Evaluation Techniques" are shown in Table 7.

Table 7. Response Words in "Measurement and Evaluation Techniques" Category

\begin{tabular}{llll}
\hline Category & Associations & Frequency (f) & $\%$ \\
\hline & Exam & 21 & 55,3 \\
& Check up Test & 4 & 10,5 \\
& Multiple Choice Test & 2 & 5,3 \\
& Written Exam & 2 & 5,3 \\
& Questionnaire & 2 & 5,3 \\
& Observation & 2 & 5,3 \\
6. Measurement and Evaluation Techniques & True-False Test & 1 & 2,6 \\
& Oral Exam & 1 & 2,6 \\
& Checklist & 1 & 2,6 \\
& Rubric & 1 & 2,6 \\
& Placement Test & 1 & 2,6 \\
\cline { 2 - 4 } & TOTAL & 38 & 100 \\
\hline
\end{tabular}

The seventh category is "Measurand" that is created using the response words given to the "measurement" key word (f=31). The response words in this category are related to the things to be measured, and the ones with the most frequencies are Information, Cognize/Understanding, Level, Topic, Concept. The response words for "Measurand" category are as in Table 8. 
Table 8. Response Words in "Measurand" Category

\begin{tabular}{llll}
\hline Category & Associations & Frequency (f) & $\%$ \\
\hline \multirow{7}{*}{ 7. Measurand } & 7 & 21,9 \\
& Information & 6 & 18,8 \\
& Cognize/Understanding & 6 & 15,6 \\
& Level & 5 & 12,5 \\
& Topic & 4 & 9,4 \\
& Concept & 3 & 6,3 \\
& Learning & 2 & 3,1 \\
& Quality & 1 & 3,1 \\
& Performance & 1 & 3,1 \\
& Measurand & 1 & 3,1 \\
& Intelligence & 1 & 3,1 \\
\hline & Reading Rate & 1 & 100 \\
\cline { 2 - 3 }
\end{tabular}

When the response words are examined, it is seen that the teacher candidates have associated the word "measurement" with the words related to "Scale". In the eighth category, "Scale" $(f=27)$ consists of the response words: Reliability, Validity, Scale, Question/Item, Ratio Scale, Interval Scale, etc. that these are shown in Table 9.

Table 9. Response Words in "Scale" Category

\begin{tabular}{llll}
\hline Category & Associations & Frequency (f) & $\%$ \\
\hline \multirow{6}{*}{ 8. Scale } & Reliability & 6 & 22,2 \\
& Validity & 4 & 14,8 \\
& Scale & 2 & 7,4 \\
& Question/Item & 2 & 7,4 \\
& Item Difficulty/ Distinctiveness Indices & 2 & 7,4 \\
& True & 2 & 7,4 \\
& False & 2 & 7,4 \\
& Ratio Scale & 2 & 7,4 \\
& Interval Scale & 2 & 3,7 \\
& Consistence & 1 & 3,7 \\
& Convenience & 1 & 3,7 \\
& Standard Deviation & 1 & 3,7 \\
& Chance Factor & 1 & 3,7 \\
\cline { 2 - 4 } & TOTAL & 1 & 100 \\
\hline
\end{tabular}

The tenth category with the lowest frequency is called "Measurements Tools" ( $f=25)$. When the answer words in this category are examined, it is seen that the teacher candidates associate the key word "measurement" to the words related to the instruments used in the measurement. These response words are Ruler, Balance (scale), Bascule, etc. as shown in Table 10.

Table 10. Response Words in "Measurement Tools" Category

\begin{tabular}{llll}
\hline Category & Associations & Frequency (f) & $\%$ \\
\hline & Ruler & 9 & 36 \\
& Balance (scale) & 6 & 24 \\
& Bascule & 6 & 24 \\
9. Measurement Tools & Tools & 2 & 8 \\
& Thermometer & 1 & 4 \\
& Standard & 1 & 4 \\
\cline { 2 - 4 } & TOTAL & 25 & 100 \\
\hline
\end{tabular}

\subsection{The Conceptual Network Related to the Conceptual Structure of Mathematics Teacher Candidates Concerning} "Measurement"

The conceptual network related to the conceptual structure of mathematics teacher candidates with regard to "measurement" is given in Figure 1. 


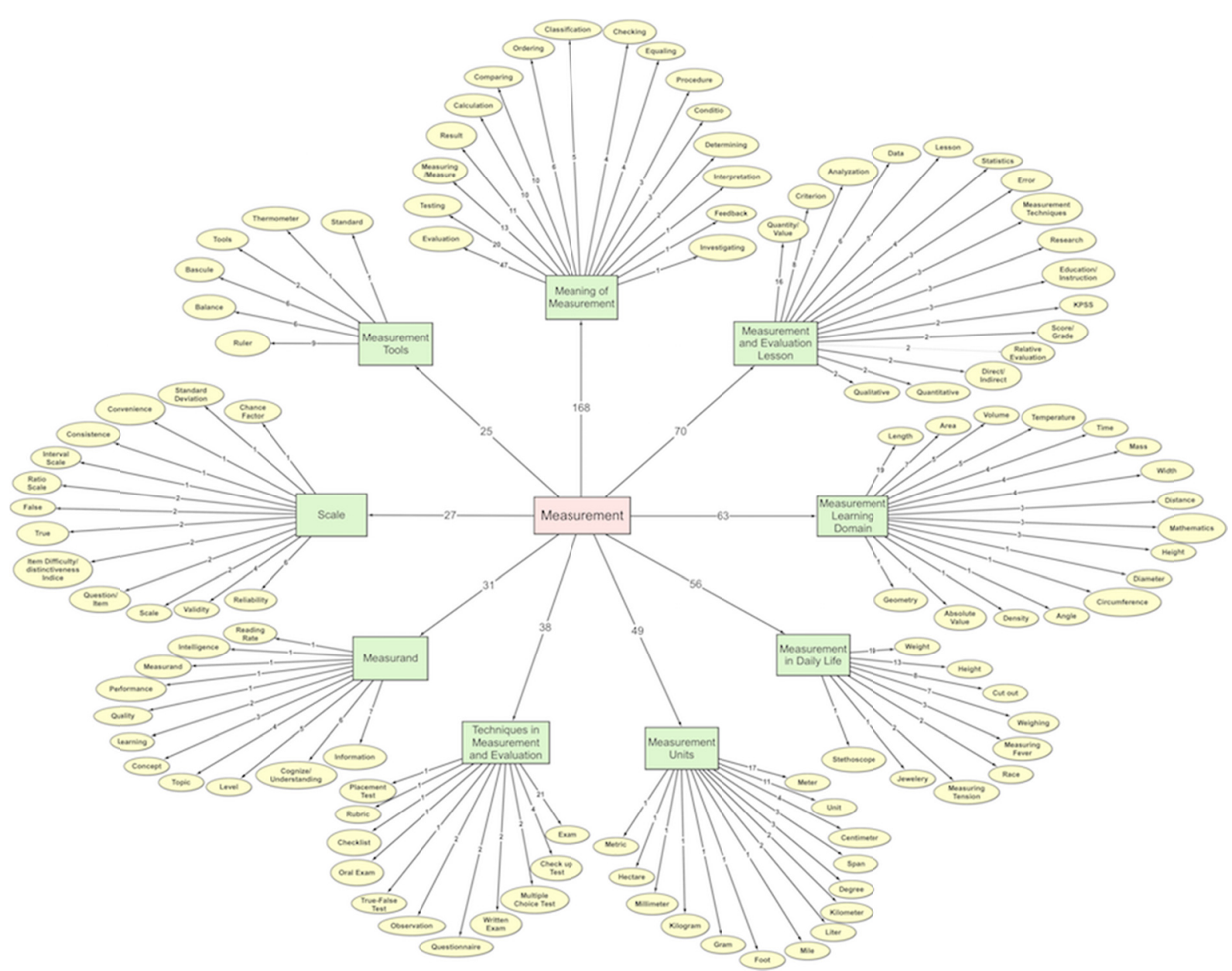

Figure 1. The Conceptual Network of Mathematics Teacher Candidates with regard to "Measurement"

The concept network in Figure 1; demonstrates the cognitive schemas of mathematics teacher candidates related to the "measurement" stimulus word. While the stimulus word presented to the teacher candidates is located at the center of the concept network, the associated words and the categories they create are located around the stimulating word together with their frequencies. Categories and response words were placed around the stimulus word in clockwise direction from the highest frequency to the lowest. Corresponding frequencies are written on the arrows that combine the words into categories and the categories with stimulating words. When the conceptual network in Figure 1 is examined, it is seen that the category with the highest frequency is the "Meaning of Measurement" ( $f=168)$ and the category with the lowest frequency is the "Measurement Tools" $(\mathrm{f}=25)$.

\section{Discussion and Conclusions}

At the end of this research, which is done to determine the cognitive structures of the "measurement" concept of mathematics teacher candidates using the free word association test, very important results have been achieved. The data obtained are given under 9 categories in total: "Meaning of Measurement", Measurement and Evaluation Lesson", Measurement Learning Domain", Measurement in Daily Life", Measurement Units", Techniques in Measurement and Evaluation", "Measurand", "Scale", and "Measurement Tools". The response words with high frequency that teacher candidates give to the "measurement" stimuli concept are "Evaluation", "Exam", "Testing", "Length", "Weight", "Meter", and "Quantity".

It is seen that the dominant category formed at the end of the research is "Meaning of Measurement" and the dominant response is "Evaluation". Teacher candidates associate the "measurement" stimuli mostly with the meaning of "measurement". As expected, the most associated response word is "evaluation" as the teacher candidates think "measurement" concept together with "evaluation" concept. As a matter of fact, an unevaluated measurement is not meaningful and the concepts of measurement and evaluation are used together in literature. The test, comparison, classification, etc. are the expected responses given by teacher candidates in "Meaning of Measurement" category. In this sense, it is seen that the teacher candidates understood the concept of measurement correctly.

It is seen that teacher candidates focus on the response words in "Measurement and Evaluation Lesson" after the 
"Meaning of Measurement" category. The response words in this category are statistics, data, criteria, analysis, quantity, etc. and when the related words are examined, it is seen that the teacher candidates mastered the basic concepts related to assessment and evaluation course. When the literature in the past years reviewed, it is emphasized that teacher candidates' proficiency in assessment and evaluation is at a low level. This situation contradicts with the findings of this study. This may be due to the increasing emphasis on assessment-evaluation in the changing teacher curriculum (MEB-TTKB, 2005) and the fact that the assessment-evaluation courses are given more than past in teacher education programs.

The third most relevant words of mathematics teacher candidates with the word "measurement" stimulus were the words in the "Measurement Learning Domain" category. Measurement learning domain is expected to be the mostly focused category of mathematics teacher candidates, because "measurement" is one of the five basic learning areas of school mathematics (MEB-TTKB, 2005; NCTM, 2000). However, it seems that the frequencies of the response words in this category are not at the expected level. It is thought to be due to the fact that the measurement learning area is regarded as the continuation of the "geometry" learning area (Delil and Gunes, 2007). In this category, the word length, area, and volume words are given as the response words. On the other hand, the fact that the circumference and the angle measuring words are given only once, and the responses such as fluid measuring and land surveying measuring are not given at all indicate that the conceptual knowledge of the teacher candidates about the measurement learning field is at a basic level.

According to the findings of the research, it is seen that the teacher candidates related the daily use of the words about measurement in the fourth place. The most related words here are weight, height, cut out, weighing. The low number of words and frequencies associated with daily life supports the findings that the teacher candidates in the literature are not at sufficient level to associate mathematical concepts with everyday life (Kayhan-Altay, 2017).

Another category that teacher candidates associate with measurement word relates to the measurement units. The most focused concept in the category of measurement units was the meter as expected. It is also seen that the responses given are related more to length measurement units. The concept that teacher candidates were mostly focused on in the measurement learning category was length. It is a state of consistency in findings of the study that lenght and lenght measurement units are related evenly. In this category, it is seen that the response words, span and foot, of non-standard measurement units are given as well as standard measurement units. It is noteworthy that the response word land surveying that is related to measurement learning field is not given, despite, the response word hectar that is a land surveying unit is given as response word. On the other side, the concepts such as volume is a word that is mostly associated with measurement stimulus word, the fact that area and volume unit are not given as response words is also a noteworthy finding.

In the "Measurement and Evaluation Techniques" category, it is seen that the mathematics teacher candidates are mainly focusing on the examination techniques called traditional methods, and they are making moderate correlations with other methods. The methods that they do not associate themselves are methods for evaluating students themselves. In the literature, it is supported by other studies that the leading evaluation method that teacher candidates see themselves insufficient is methods based on student evaluation (Birgin \& Gurbuz, 2008; Gelbal \& Kelecioğlu, 2007; Senel-Coruhlu, Er-Nas, and Cepni, 2009).

When the response words in the "measurand" category are examined, it is seen that responses such as knowledge, comprehension, concept, and learning are given as measured. Teacher candidates' giving these responses is an expected situation. The fact that those who give the responses as measured do not give the score unit response, which is the unit of measure, suggests that the teacher candidates can not establish a sufficient relationship between the measured and the units of measurement.

Another category created from the response words was "Scale". When the response words and frequencies in this category are examined, it is seen that very few of the teacher candidates have a grasp of general concepts related to the scale.

When the responses given in the "Measurement Tools" category are examined, it is seen that the response with the highest frequency is "ruler", which is a tool for measuring the length. When the length and the metric are considered to have high frequencies too, the high frequency response of the ruler is a consistent finding. It is noteworthy that the thermometer response is given in this category while the heat and temperature responses are not included in the measurand category.

As a result, when the words associated to the concept of "measurement" are examined, it can be said that these associations are gathered in the general sense around the four components of the definition of measurement made by Zembat (2013): comparison-quality-quantity-unit. In particular, the cognitive structures of teacher candidates about "measurement" concept are shaped around "measurement-evaluation course" rather than "measurement learning 
domain". In this sense, it may be suggested that the "measurement learning domain" should be included more in mathematics curriculum and teacher training curriculums. Also, it can be recommended to use write and draw technique besides word association test in order to determine misconceptions and alternative concepts as well as determining the cognitive structures of students.

\section{References}

Atasoy, B. (2004). Fen öğrenimi ve ögrretimi. Ankara: Asil Yayınevi.

Ay, M. (2011). Conceptual frameworks of university students regarding accounting. African Journal of Business Management, 5(5), 1570-1577.

Bahar, M., Johnstone, A. H., \& Sutcliffe, R. (1999). Investigation of students' cognitive structure in elementary genetics through word association tests. Journal of Biological Education, 33(3),134-141. https://doi.org/10.1080/00219266.1999.9655653

Baki, A., \& Kartal, T. (2004). Characterizing high school students' algebra knowledge in terms of procedural and conceptual knowledge. The Journal of Turkish Education Sciences, 2(1), 27-46.

Bekdemir, M. (2012). Evaluation of elementary preservice teachers' conceptual and procedural knowledge on circle and disk. Hacettepe University Education Journal of Education, 43, 83-95.

Benibil, O., \& Erdogan, A. (2016a, November). Examining prospective mathematics teachers' cognitive structure on the concept of "statistics". Paper presented at the 1st International Academic Research Congress (INES), Antalya, Turkey (pp. 2593-2600).

Benibil, O., \& Erdogan, A. (2016b, November). Examining the prospective mathematics teachers' cognitive structure on the concept of "probability". Paper presented at the 1st International Academic Research Congress (INES). Antalya, Turkey (pp. 2601-2608).

Birgin, O., \& Gurbuz, R. (2008). Examining of class teacher candidates' knowledge levels about measurement and evaluation topic Journal of Selcuk University Intitute of Social Sciences, 20, 163-179.

Birgin, O., \& Gurbuz, R. (2009). Examining the secondary school students' proceduaral and conceptual knowledge levels about rational numbers topic Journal of Uludag University Faculty of Education, 22(2), 529-550.

Bogdan, R. C., \& Biklen, S. K. (2007). Qualitative research for education (5th ed). Boston: Pearson Education, Inc.

Bright, G. W. (1976). Estimation as part of learning to measure. In D.Nelson \& R.E. Reys (Eds.), Measurement in school mathematics: 1976 Yearbook (pp. 87-104). Reston, VA: National Council of Teachers of Mathematics, Inc.

Cohen, L., Manion, L., \& Morrison, K. (2007). Research methods in education (6th ed.). New York, NY: Routledge.

Common Core State Standards Initiative (CCSSI). (2010). Common core state standards for mathematics. (12.08.2017) retrieved from http://www.corestandards.org/wp-content/uploads/Math_Standards.pdf

Daskolia, M., Flogaitis, E., \& Papageorgiou, E. (2006). Kindergarten teachers' conceptual framework on the ozone layer depletion. Exploring the associative meanings of a global enviromental issue. Journal of Science Education and Technology, 5(2), 168-178. https://doi.org/10.1007/s10956-006-9004-8

Daymon, C., \& Holloway, I. (2003). Qualitative research methods in public relations and marketing communications. London: Rout ledge.

Delil, A., \& Güleş, S. (2007). An evaluation of geometry and measure sections of the new sixth grade primary mathematics curricula according to constructivist learning approach. Journal of Education Faculty, XX(1), 35-48.

Dikmenli, M. (2010a). Biology student teachers' conceptual frameworks regarding biodiversity. Education 130(3), 479-489.

Dikmenli, M. (2010b). Biology students' conceptual structures regarding global warming. Energy Education Science and Technology Part B: Social and Educational Studies, 2(1), 21-38.

Erdogan, A. (2007). Usage of concept mapping in calculus teaching (Unpublished doctoral dissertation). University of Selcuk, Konya, Turkey.

Erdogan, A. (2017). Examining Pre-service Mathematics teachers' conceptual structures about "Geometry". Journal of Education and Practice, 8(27), 65-74.

Gelbal, S., \& Kelecioğlu, H. (2007). Teachers' proficiency perceptions of about the measurement and evaluation techniques and the problems they comfort. Hacettepe University Journal of Education, 33, 135-145.

Given, L. M. (Ed.) (2008). The sage encyclopedia of qualitative research methods. Sage: Thousand Oaks, CA, 2, 
697-698. https://doi.org/10.4135/9781412963909

Gokbas, H., \& Erdogan, A. (2016). Prospective mathematics teachers' conceptual structure about Function. Journal of Research in Education and Teaching, 5(3), 208-217.

Hiebert, J., \& Lefevre, P. (1986). Conceptual and procedural knowledge in mathematics: An introductory analysis. In J. Hiebert (Ed.), Conceptual and procedural knowledge: The case of mathematics (pp. 1-27). Hillsdale, NJ: Erlbaum.

Hovardas, T., \& Korfiatis, K. J. (2006). Word Associations as a Tool for Assessing Conceptual Change in Science Education. Learning and Instruction, 16, 416-432. https://doi.org/10.1016/j.learninstruc.2006.09.003

Hruschka, D. J., Schwartz, D., St.John, D. C., Picone-Decaro, E., Jenkins, R. A., \& Carey, J. W. (2004). Reliability in coding open-ended data: Lessons learned from HIV behavioral research. Field Methods, 16 (3), $307-331$. https://doi.org/10.1177/1525822X04266540

Kayhan-Altay, M., Yalvaç, B., \& Yeltekin, E. (2017). 8th grade student's skill of connecting mathematics to real life. Journal of Education and Training Studies, 5(10), 158-166. https://doi.org/10.11114/jets.v5i10.2614

Keser, S. (2017). Investigation of the cognitive structures of mathematics teachers on the concept of trigonometry (Unpublished master's thesis). University of Necmettin Erbakan, Konya, Turkey.

Knight, S. L., Nolan, J., Lloyd, G., Arbaugh, F., Edmondson, J., \& Whitney, A. (2013). Quality teacher education research: How do we know it when we see it? Journal of Teacher Education, 64(2), 114-116. https://doi.org/10.1177/0022487112469941

Kostova, Z., \& Radoynovska, B. (2008). Word association test for studying conceptual structures of teachers and students. Bulgarian Journal of Science and Education Policy, 2 (2), 209-231.

Kostova, Z., \& Radoynovska, B. (2010). Motivating students' learning using word association test and concept maps. Bulgarian Journal of Science and Education Policy (BJSEP), 4(1), 62-98.

Kurt, H., \& Ekici, G. (2013a). Determining biology student teachers' cognitive structure and alternative concepts on the concept of "bacteria." International Periodical For The Languages, Literature and History of Turkish or Turkic, $8(8), 885-910$.

Kurt, H., \& Ekici, G. (2013b). What is a virus? Prospective biology teachers' cognitive structure on the concept of Virus. International Online Journal of Educational Sciences, 5(3), 736-756.

Lichtman, M. (2010). Qualitative research in education. Los Angeles: Sage Publications, Inc.

Miles, M. B., \& Huberman, A. M. (1994). Qualitative data analysis: an expanded sourcebook (2nd ed.). Londan: Sage Publications.

Ministry of Education Training Chair (MEB-TTKB). (2017). Curriculum of math lesson. Ankara: State Books Directorate.

National Council of Teachers of mathematics (NCTM). (2000). Principles and standards for school mathematics. Reston, VA: Author.

Olkun, S., \& Toluk, U. Z. (2004). Activity based mathematics instruction at elementary education. Ankara: Ani Publishing.

Ozata-Yucel, E., \& Ozkan, M. (2015). Determination of secondary school students' cognitive structure, and misconception in ecological concepts through word association test. Educational Research and Reviews, 10(5), 660-674. https://doi.org/10.5897/ERR2014.2022

Ozatlı, N. S. (2006). Determination of the topics perceived as difficult by the students in biology lessons and putting forth their cognitive structures about excretion system for consideration by new techniques (Unpublished doctoral dissertation). University of Balıkesir, Balıkesir, Turkey.

Papadakis, S., Kalogiannakis, M., \& Zaranis, N. (2016). Improving mathematics teaching in kindergarten vith realistic mathematical education. Early Childhood Education Journal, 45, 369. https://doi.org/10.1007/s10643-015-0768-4

Post, T., \& Cramer, K. (1989, March). Knowledge, representation and quantitative thinking. In M. Reynolds (Ed.), Knowledge base for the beginning teacher (pp. 221-231). Oxford: Pergamon Press.

Ratcliff, D. (1995). Validity and Reliability in Qualitative Research. Retrieved from http://qualitativeresearch.ratcliffs.net/Validity.pdf (Accessed: c27 September 2010).

Rittle-Johnson, B., \& Koedinger, K. R. (2009). Iterating between lessons concepts and procedures can improve mathematics knowledge. British Journal of Educational Psychology, 79(3), 483-500. 
https://doi.org/10.1348/000709908X398106

Rittle-Johnson, B., Siegler, R. S., \& Alibali, M. W. (2001). Developing conceptual understanding and procedural skill in mathematics: An iterative process. Journal of Educational Psychology, 93(2), 346-362. https://doi.org/10.1037/0022-0663.93.2.346

Schmitt, N. (1998). Quantifying word association responses: what is native-like? System, 26(1998), 389-401. https://doi.org/10.1016/S0346-251X(98)00019-0

Senel-Coruhlu, T., Er-Nas, S., \& Cepni, S. (2009). Problems facing science and technology teachers using alternative assessment technics: Trabzon sample. Journal of Yuzuncu Yil University Faculty of Education, 6(1), 122-141.

Shavelson, R. J. (1974). Methods for examining representations of a subject-matter structure in a student's memory. Journal of Research in Science Teaching, 11, 231-249. https://doi.org/10.1002/tea.3660110307

Skemp, R. R. (1978). Relational understanding and instrumental understanding. Arithmetic Teacher, 26(3), 9-15.

Skemp, R. R. (1987). The psychology of learning mathematics. Hillsdale, NJ: Erlbaum.

Stemler, S. (2001). An overview of content analysis. Practical assessment. Research \& Evaluation, 7(17), 1-8.

Torkar, G., \& Bajd, B. (2006). Trainee teachers' ideas about endangered birds. Journal of Biological Education, 4l(1), 5-8. https://doi.org/10.1080/00219266.2006.9656049

Turan, S. B., \& Erdogan, A. (2016). Prospective mathematics teachers' conceptual structure about Continuity. Journal of Research in Education and Teaching, 5(3), 194-207.

Turan, S. B., \& Erdogan, A. (2017). Investigation of prospective mathematics teachers' conceptual structure about Limit. Journal of Research in Education and Teaching, 6(1), 397-410.

Weber, P. W. (1990). Basic content analysis (2nd Edition). California: Sage Publications. https://doi.org/10.4135/9781412983488

Wimmer, R. D., \& Dominick, J. R. (2000). Mass media research: An introduction. Belmont: Wadsworth Publishing Company.

Yıldırım, A., \& Şimşek, H. (2006). Qualitative research methods in social sciences. Ankara: Seçkin Publishing.

Zembat, İ. Ö. (2013). Measurement concret with mathematical analysis and length, area, and volume qualities İ.Ö. Zembat, M.F. Özmantar, E. Bingölbali, H. Şandır, and A. Delice (Eds.), Mathematical concepts with definition and historical development, (pp. 139-152). Ankara: Pegem Akademi Publishing.

\section{Copyrights}

Copyright for this article is retained by the author(s), with first publication rights granted to the journal.

This is an open-access article distributed under the terms and conditions of the Creative Commons Attribution license which permits unrestricted use, distribution, and reproduction in any medium, provided the original work is properly cited. 